\title{
MANAJEMEN KOMUNIKASI DINAS PARIWISATA KEBUDAYAAN, KEPEMUDAAN DAN OLAHRAGA DALAM MENGEMBANGKAN POTENSI DESA WISATA DI KABUPATEN BENGKALIS
}

\author{
Nova Yohana, Yasir, Rumyeni \\ Jurusan Ilmu Komunikasi, Fakultas Ilmu Sosial Ilmu Politik, Universitas Riau \\ Kampus Bina Widya Jl. Hr. Soebrantas KM. 12.5 Simp. Baru Pekanbaru-28293 \\ nova.yo7@gmail.com
}

\begin{abstract}
ABSTRAK
Penelitian ini bertujuan untuk mengetahui dan menganalisis manajemen komunikasi yang dilakukan Disparbudpora yakni perencanaan, pengorganisasi, penggerakan, pengawasan dan evaluasi komunikasi dalam program pengembangan potensi Desa Wisata di Kabupaten Bengkalis. Metode penelitian ini adalah metode kualitatif. Teknik penentuan informan dilakukan secara purposif yaitu dengan memilih informan yang dianggap tahu dan dapat dipercaya untuk menjadi sumber data. Teknik pengumpulan data dilakukan dengan wawancara, studi dokumentasi dan observasi. Teknik analisis data menggunakan model model analisis interaktif Miles dan Hubermann. Teknik keabsahan data melalui triangulasi, dan perpanjangan keikutsertaan. Hasil penelitian menunjukkan bahwa pada proses perencanaan komunikasi dimulai dari pemetaan potensi sumber daya alam untuk kawasan pedesaan yang layak dikembangkan menjadi Desa Wisata, analisis kesiapan pemerintah, masyarakat dan pihak swasta, serta perencanaan anggaran dalam kegiatan anggaran APBD. Pada proses pengorganisasian dan penggerakan melalui koordinasi berupa komunikasi vertikal dan horizontal dengan pembentukan Unit pelayanan terpadu (UPT), badan pengelola desa wisata dan kelompok sadar wisata. Pelaksanaan pengembangan potensi desa wisata dilakukan dengan memanfaatkan potensi sumber daya alam dan sumber daya manusia yang ada. Pengawasan dan evaluasi komunikasi belum sepenuhnya dilakukan Disparbudpora dikarenakan program pengembangan potensi Desa Wisata Kabupaten Bengkalis baru dimulai dan belum sepenuhnya mendapat dukungan dari, pemerintah, masyarakat dan pihak swasta.

Kata kunci: Manajemen Komunikasi, Komunikasi Pariwisata, Desa Wisata
\end{abstract}

\section{PENDAHULUAN}

Pariwisata merupakan salah satu aspek pembangunan yang dewasa ini mendapatkan perhatian lebih, baik dari pemerintah pusat maupun daerah. Berbagai upaya pengembangan potensi wisata terus dilakukan pemerintah, hal ini dikarenakan pariwisata memiliki peranan yang sangat potensial dan strategis dalam pembangunan daerah dan turut menunjang pembangunan nasional sekaligus merupakan salah satu faktor yang sangat strategis untuk meningkatkan pendapatan perekonomian nasional dan daerah. Sektor pariwisata yang baru-baru ini sedang digencarkan oleh Kementerian Pariwisata yaitu dibangunnya desa wisata di berbagai wilayah Indonesia. Program Desa Wisata adalah salah satu upaya 
pemerintah membangun destinasi pariwisata yang bertujuan untuk meningkatkan sektor pariwisata dan ekonomi masyarakat desa. Kementerian Pariwisata dan Ekonomi Kreatif telah menargetkan pengembangan 2.000 desa wisata melalui program nasional pemberdayaan masyarakat (PNPM) Mandiri Pariwisata. Menurut Peraturan Menteri Kebudayaan Dan Pariwisata Nomor: PM.26/ UM.001/MKP/2010 tentang pedoman umum program nasional pemberdayaan masyarakat (PNPM) mandiri pariwisata melalui desa wisata yang dimaksud Desa Wisata adalah suatu bentuk integrasi antara atraksi, akomodasi dan fasilitas pendukung yang disajikan dalam suatu struktur kehidupan masyarakat yang menyatu dengan tata cara dan tradisi yang berlaku.

Kabupaten Bengkalis merupakan salah satu Kabupaten di Propinsi Riau yang memiliki posisi strategis dalam pengembangan pariwisata, kondisi geografis Kabupaten Bengkalis yang berhadapan langsung dengan pelayaran internasional, yaitu Selat Malaka dan berada dalam kawasan segitiga pertumbuhan, yakni segitiga pertumbuhan Indonesia-Malaysia-Singapura dan Indonesia-Malaysia-Thailand (Indonsia Ecotourism Network, 2002). Keunggulan kabupaten ini adalah daerahnya memiliki pantai yang sangat berpotensi sebagai destinasi wisata unggulan, yaitu: Pantai Rupat Utara di Pulau Rupat dan Pantai Selat Baru di Pulau Bengkalis.

Pemerintah Kabupaten Bengkalis melalui Dinas Kebudayaan, Pariwisata, Pemuda dan Olahraga telah mempersiapkan rancangan desa wisata sebagai acuan dalam pengembangan potensi pariwisata yang ada di Kabupaten Bengkalis. Kabupaten Bengkalis memiliki berbagai potensi wisata yang dapat menarik perhatian calon pengunjung jika dikelola dengan baik, yaitu: wisata alam, wisata sejarah/budaya. Untuk wisata alam Kabupaten Bengkalis memanfaatkan potensi pantai misalnya Pantai Rupat, Pantai Selat Baru, Pantai Prapat Tunggal, Pantai Parit Tiga, selain pantai sebagai objek wisata Bengkalis memiliki pusat pelatihan gajah sebagai objek wisata fauna, untuk objek wisata sejara. Budaya seperti di Kecamatan Bukit Batu yang memiliki peninggalan sejarah kebudayaan atau adat istiadat Bengkalis. Semua potensi wisata yang ada di Kabupaten Bengkalis lewat Dinas Kebudayaan, Pariwisata, Pemuda dan Olahraga telah merancang program pengembangan objek wisata tersebut menjadi desa wisata.

Setiap desa di kabupaten ini memiliki potensi untuk dijadikan komoditas wisata unggulan. Keindahan dan keunikan alam akan menjadi wisata alam. Selain itu, desadesa tersebut juga memiliki keunikan tradisi dan budayanya bisa menjadi destinasi wisata budaya. Jika desa tersebut memiliki menu makanan dan minuman khas tradisional yang unik baik dari bahan, rasa dan penyajiannya, bisa dijadikan destinasi wisata kuliner desa. Jika desa tersebut memiliki kerajinankerajinan khas nan unik bisa menjadi destinasi wisata suvenir desa. Atau jika desa tersebut memiliki peninggalan-peninggalan yang mempunyai nilai sejarah yang tinggi atau situs sejarah/prasejarah bisa menjadi 
tujuan wisata sejarah desa. Pengembangan desa wisata memerlukan manajemen dan pelaksanaan yang melibatkan seluruh lapisan, tidak hanya melibatkan perhatian dari pemerintah tetapi juga masyarakat dan para stakeholder yang nantinya akan menjadi bagian pelaksana atau pengelola dari program desa wisata. Oleh karena itu kesiapan desa wisata harus diimbangi dengan kemampuan untuk membangun jejaring pasar dengan para pelaku industri pariwisata, dengan berbagai bentuk kerjasama dan pengembangan media promosi sehingga potensi desa tersebut muncul dalam peta produk dan pemaketan wisata di daerah, regional, nasional maupun internasional.

Keberhasilan kegiatan komunikasi banyak ditentukan oleh manajemen komunikasi yang diterapkan. Di lain pihak jika tidak ada manajemen komunikasi yang baik, efek dari proses komunikasi bukan tidak mungkin akan menimbulkan pengaruh negatif. Manajemen komunikasi yang baik dalam suatu organisasi akan menentukan tingkat keberhasilan dari organisasi tersebut dalam mencapai target dan sasaran. Manajemen komunikasi akan mengarahkan cara dan pola komunikasi kepada orang-orang yang berada di dalam organisasi (internal) dan orang-orang yang memungkinkan akan terlibat dalam aktivitas organisasi (eksternal). Arah pengembangan kawasan desa wisata di Kabupaten Begkalis diarahkan kepada komitmen yang kuat dari aktor-aktor atau agen-agen yang terlibat, negara, pemerintah (provinsi, kabupaten, desa), masyarakat, perguruan tinggi dan sektor swasta termasuk individu untuk bersatupadu saling terkoordinasi dalam sistem baku menjadikan desa di kawasan ini sebagai kawasan wisata sejarah-budaya, desa wisata industri kerajinan, desa wisata perairan dan desa wisata kuliner khas Melayu. Berdasarkan uraian diatas, maka penelitian ini difokuskan pada sebuah studi mengenai Model Manajemen Komunikasi Program Pengembangan Potensi Desa Wisata di Kabupaten Bengkalis.

Maksud dari penelitian ini adalah untuk mengetahui dan menganalisis perencanaan (planning), bentuk pengorganisasian (organizing), penggerakan (actuating), metode pengawasan dan evaluasi (evaluating) komunikasi Dinas Pariwisata Kebudayaan Kepemudaan dan Olahraga dalam program pengembangan potensi desa wisata di Kabupaten Bengkalis.

\section{KAJIAN TEORITIS}

West \& Turner mengemukakan bahwa komunikasi adalah proses sosial di mana individu-individu menggunakan simbol-simbol untuk menciptakan dan menginterpretasikan makna dalam lingkungan mereka (West \& Turner, 2008: 5). Dance (dalam Mulyana, 2001: 54-55) mengemukakan tiga dimensi konseptual penting yang mendasari komunikasi. Dimensi pertama adalah tingkat obeservasi (level of obesrvation), atau derajat keabstrakannya. Dalam hal ini, komunikasi sebagai "proses yang menghubungkan satu sama lain bagianbagian terpisah dunia kehidupan" adalah terlalu umum. Sementara komunikasi sebagai "alat untuk mengirim pesan militer, perintah, 
dan sebagainya melalui telepon, radio, kurir, dan sebagainya" adalah terlalu sempit.

Dimensi kedua adalah kesengajaan (intensionality). Sebagian definisi mencakup hanya pengiriman dan penerimaan pesan yang disengaja, sebagian definisi lainnya tidak menuntut syarat ini. Gerald R. Miller menjelaskan bahwa komunikasi sebagai "situasi-situasi yang memungkinkan suatu sumber mentransmisikan suatu pesan kepada seseorang penerima dengan disadari untuk mempengaruhi penerima”. Sedangkan definisi yang mengabaikan kesengajaan adalah definisi yang dinyatakan Alex Gobe, yakni "suatu proses yang membuat sama bagi dua orang atau lebih, apa yang tadinya merupakan monopoli seseorang atau sejumlah orang" (dalam Mulyana, 2001:55).

Dimensi ketiga adalah penilaian normatif. Komunikasi mensyaratkan adanya keberhasilan atau kecermatan, sementara yang lainnya tidak seperti itu. John B Hoben mengasumsikan bahwa komunikasi harus berhasil: "Komunikasi adalah pertukaran verbal pikiran atau gagasan". Dalam asumsi ini secara implisit mensyaratkan bahwa suatu pikiran atau gagasan harus dapat dipertukarkan. Sebagian yang lain seperti definisi komunikasi Bernard Berelson dan Gary Steiner; "Komunikasi adalah transmisi informasi". Dalam definisi ini tidak mensyaratkan bahwa informasi harus diterima atau dimengerti.

Manajemen komunikasi adalah manajemen yang diterapkan dalam kegiatan komunikasi. Ini berarti manajemen akan berperan atau sebagi penggerak aktivitas komunikasi dalam usaha pencapaian tujuan komunikasi. Manajemen komunikasi adalah ilmu yang mempelajari bagaimana mengelola informasi untuk mencapai tujuan (dalam Tommy Suprapto, 2009: 144). Setiap aktivitas pendistribusian pesan dan atau informasi adalah aktivitas komunikasi.

Menurut E. Guyer Freuler merumuskan pengertian pariwisata sebagai berikut: "pariwisata dalam artian modern merupakan fenomena dari zaman sekarang yang didasarkan atas kebutuhan akan kesehatan, pergantian suasana, penilaian yang sadar dan menumbuhkan (cinta) terhadap keindahan alam dan pada khususnya disebabkan oleh bertambahnya pergaulan berbagai bangsa dan kelas masyarakat manusia sebagai hasil daripada perkembangan perniagaan, industri, serta penyempurnaan daripada alat-alat pengangkutan” (A. Yoeti Oka, 2008 : 84).

Haryono (2011:15) mengatakan bahwa parwisata berasal dari bahasa Sansekerta yaitu: "Pari" yang berarti banyak, berkalikali, berputar-putar, dan keliling, dan "Wisata" yang berarti perjalanan atau bepergian. Jadi, kata pariwisata diartikan sebagai perjalanan yang dilakukan berkalikali atau berputar-putar dari suatu tempat ke tempat lain. Untuk memperjelasnya, maka dapat disimpulkan definisi pariwisata adalah sebagai berikut: "Pariwisata adalah suatu perjalanan yang dilakukan untuk sementara waktu, yang diselenggarakan dari suatu tempat ke tempat yang dengan maksud bukan untuk berusaha (business) atau mencari nafkah di tempat yang dikunjungi, tetapi semata-mata untuk menikmati perjalanan 
tersebut guna bertamasya dan rekreasi atau untuk memenuhi keinginan yang beragam.

Pada era sekarang ini Pariwisata dipandang sebagai bisnis modern dikarenakan konsep pariwisata yang mendefinisikan dirinya sebagai produk bisnis modern. Jadi semua produk pariwisata didesain sebagai produk bisnis, mulai dari destinasi, ekonomi kreatif, transportasi, perhotelan, venue rekreasi, atraksi seni dalam paketpaket wisata yang menarik, mengagumkan, menantang, dan mengesankan. Pariwisata modern bersentuhan dengan sektor-sektor bisnis, sebab pariwisata ataupun tidak telah menjadi produk yang dijualkan kepada orang luar (Haryono, 2011 : 45). Johnpaul (2014:34) mengatakan, komponen utama pariwisata adalah terdiri dari: 1) aksesibilitas, 2) akomodasi, 3) atraksi. Adapun menurut Ramesh komponen pariwisata terpenting adalah: 1) akomodasi, 2) aksesibilitas, 3) fasilitas, 4) atraksi dan 5) aktivitas.

Komponen dan elemen-elemen pariwisata itu terus akan berkembang sesuai dengan kreatifitas stakeholder pariwisata di suatu destinasi negara atau destinasi venue wisata. Kemajuan teknologi informasi dan transportasi saat ini menyebabkan berbagai destinasi dapat berinteraski dan dengan mudah saling bertukar pengalaman, sehingga perkembangan destinasi disesuaikan dengan kekuatan modal destinasi pariwisata. Hukum ekonomi berlaku dalam perkembangan destinasi. Data awal tentang jumlah kunjungan wisata, baik domestik maupun wisata mancanegara menjadi dasar dan alasan yang kuat masuknya modal inventasi di destinasi-destinasi berprospektif.

Bungin (2015:46) mengatakan komunikasi membantu pemasaran pariwisata di berbagai elemen pemasaran, komunikasi berperan baik di media komunikasi maupun konten komunikasi. Di media komunikasi, tersedia berbagai macam media komunikasi sebagai saluran pemasaran, destinasi, aksesibilitas maupun saluran media SDM dan kelembagaan pariwisata. Komunikasi juga berperan menyiapkan konten pesan yang harus disampaikan kepada masyarakat atau wisatawan, tentang apa yang seharusnya mereka tahu tentang media-media pemasaran, tentang destinasi, aksesibilitas dan SDM serta kelembagaan pariwisata. Dalam perspektif modern, komponen pemasaran, destinasi, aksesibilitas, SDM, dan kelembagaan pariwisata, serta elemenelemen yang ada menjadi kesatuan produk pariwisata di sebuah destinasi yang dikemas di dalam suatu brand destinasi, sehingga destinasi, aksesibilitas, pemasaran, SDM dan kelembagaan pariwisata menjadi kesatuan produk pariwisata. Komunikasi pariwisata berkembang dari menyatunya beberapa disiplin ilmu di dalam kajian komunikasi dan pariwisata (Bungin, 2015). Kajian komunikasi pariwisata memiliki kedekatan biologis dengan kajian komunikasi dan pariwisata.

Desa wisata adalah sebuah kawasan pedesaan yang memiliki beberapa karakteristik khusus untuk menjadi daerah tujuan wisata. Di kawasan ini, penduduknya masih memiliki tradisi dan budaya yang relatif masih asli. Selain itu, beberapa faktor 
pendukung seperti makanan khas, sistem pertanian dan sistem sosial turut mewarnai sebuah kawasan desa wisata. Desa wisata adalah suatu wilayah pedesaan yang menawarkan keaslian baik dari segi sosial budaya, adat-istiadat, keseharian, arsitektur tradisional, struktur tata ruang desa yang disajikan dalam suatu suatu bentuk integrasi komponen pariwisata antara lain seperti atraksi, akomodasi dan fasilitas pendukung (Darsono, 2005).

\section{METODE PENELITIAN}

Metode yang digunakan dalam penelitian ini adalah metode penelitian kualitatif. Moleong (2007:6) menjelaskan, bahwa penelitian kualitatif adalah penelitian yang bermaksud untuk memahami fenomena tentang apayang dialamiolehsubjekpenelitian secara holistik (utuh) dan dengan cara deskripsi dalambentuk kata-kata dan bahasa pada suatu konteks khusus yang alamiah, sertadengan memanfaatkan berbagai metode alamiah yang salah satunya bermanfaat untuk keperluan meneliti dari segi prosesnya. Data dalam penelitian ini dikumpulkan berdasarkan pengelompokan data primer dan data sekunder. Oleh karena penelitian ini menggunakan metode kualitatif, maka teknik pengumpulan data yang digunakan adalah dengan melakukan observasi dengan cara atau pengamatan berperan serta (participant observation) sebagai teknik utama, wawancara mendalam (in-depth interview), dan penggunaan dokumentasi (documentation). Informan terdiri dari: Pihak Dinas Kebudayaan, Pariwisata,
Pemuda dan Olahraga (Disparbudpora) dan masyarakat yang menjadi kelompok sasaran pengembangan desa wisata. Teknik Pengambilan Sampel Pengambilan sampel dalam penelitian ini adalah dengan teknik purposif di mana peneliti memilih informan yang dapat dipercaya untuk menjadi sumber informasi dan dianggap mengetahui perihal pengambangan desa wisata secara mendetail. Teknik analisis data menggunakan model model analisis interaktif Miles dan Hubermann. Teknik keabsahan data melalui triangulasi, dan perpanjangan keikutsertaan.

\section{HASIL PENELITIAN DAN DISKUSI}

Pemerintah Kabupaten Bengkalis berusaha untuk mengembangkan desa menjadi desa wisata melalui konsep yang sederhana. Program pengembangan desa wisata adalah bentuk dari pengembangan dan memajukan objek pariwisata. Desa yang memiliki keunggulan dan kekayaan alam, budaya dan kesenian diharapkan menjadikan pemicu untuk peningkatan kunjungan wisatawan. Desa Meskom dan Perapat Tunggal di Kecamatan Bengkalis, Desa Selat Baru dan Muntai di Kecamatan Bantan, Desa Tanjung Punak dan Teluk Rhu di Kecamatan rupat Utara selain memiliki wisata alam juga memiliki potensi seni, budaya, tradisi dengan objek-objeknya yang menawan juga merupakan penghasil produk olahan yang bernilai ekonomis.

Desa Meskom memiliki keunggulan antara lain: rumah panggung karna bentuknya yang tinggi dan unik, dan rumah balak kalau bentuk bangunannya rendah. Memiliki 
makanan khas daerah yaitu belacan, cencaluk, tempoyak, asam pedas, dan kepurun yang bahannya dari sagu. Desa Meskom memiliki nama lain yakni: "Kampung Zapin". Meskipun, tak semua warga Meskom paham dan memahami zapin secara mendalam tapi dalam satu keluarga tak ada yang tak bisa memainkan zapin. Selain kesenian zapin warga desa juga memiliki jenis kesenian lain yaitu kompang, robana, dan pencak silat. Selain itu juga desa ini punya permainan yang bisa menarik untuk dinikmati oleh wisatawan antara lain permainan tradisional seperti jung, gasing, dan layang (Yasir, Nurjanah \& Yeshica, 2016: 233).

Pemerintah Bengkalis telah berusaha mengembangkan desa wisata ini menjadi andalan pemerintah daerah ini untuk meningkatkan citra parwisata Kabupaten Bengkalis. Beberapa kegiatan tahunan sering dibuat untuk menunjang dan mempromosikan daerah wisata ini. Beberapa kegiatan yang dilakukan adalah festival pantai Selat Baru dengan berbagai perlombangan-perlombaan, festival pantai rupat, ritual mandi safar, dan lain sebagainya. Kegiatan-kegiatan ini merupakan bagian dari manajemen komunikasi untuk mengembangkan desa wisata di Bengkalis.

Dalam hal ini jelas bahwa setiap aktivitas pendistribusian pesan dan atau informasi adalah aktivitas komunikasi. Guna mencapai tingkatan keberhasilan dalam aktivitas komunikasi yang meliputi aktivitas pencarian, pengumpulan, dan pengolahan serta pendistribusian informasi selalu memerlukan manajemen. Manajemen komunikasi adalah manajemen yang diterapkan dalam kegiatan komunikasi. Ini berarti manajemen akan berperan atau sebagi penggerak aktivitas komunikasi dalam usaha pencapaian tujuan komunikasi. Manajemen komunikasi adalah ilmu yang mempelajari bagaimana mengelola informasi untuk mencapai tujuan (dalam Tommy Suprapto, 2009: 144). Menurut Michael Kaye (1994:8) dalam Soedarsono (2009) "Bagaimana individu atau manusia mengelola proses komunikasi melalui penyusunan kerangka makna dalam hubungannya dengan orang lain dalam berbagai lingkup komunikasi dengan mengoptimalisasi sumberdaya komunikasi dan teknologi yang ada".

Menurut Baker dalam Claywood (1977: 461-63) mengatakan manajemen komunikasi pemerintah secara taktikal meliputi tiga hal: pertama, identifikasi isu secara fokus menyangkut kebijakan atau program sudah dikemas sesuai dengan karakteristik yang diinginkan. Ketiga, mengeksekusi perencanaan komunikasi. Empat langkah manajemen komunikasi secara operasional mengacu pada pendekatan Cutlip, Center dan Broom's Palanning and Management Methods's (Defining Public Problems, Planning and Programming, Taking Action and Communicating, Evaluating the Program. secara umum, definisi manajemen komunikasi adalah proses pengelolaan sumberdaya komunikasi yang ditujukan untuk meningkatkan kualitas dan efektivitas pertukaran pesan yang terjadi dalam berbagai konteks komunikasi (individual, organisasional, govermental, sosial, atau internasional). 
Perencanaan komunikasi pada dasarnya melibatkan aspek-aspek atau unsur-unsur yang membentuk kesatuan komunikasi, yaitu komunikator, pesan, komunikan, media dan efek. Dalam manajemen komunikasi, pada aspek perencanaan, sumber daya menyusun perencanaan untuk komunikator, pesan, media, khalayak (komunikan) dan rencana pengaruhnya atau efek (Suprapto, 2011: 140). Kegiatan perencanaan menjadi salah satu hal yang penting dalam perencanaan pengembangan potensi desa wisata di Kabupaten Bengkalis. Perencanaan komunikasi, perlu untuk mengidentifikasi stakeholders dan kebutuhannya serta menentukan bagaimana mencapainya. Kegiatan perencanaan disini berupa bentuk persiapan dalam pengembangan potensi Desa wisata di Kabupaten Bengkalis.

Hal ini dimulai dari pemetaan terhadap potensi sumber daya alam di beberapa Desa yang layak untuk dikembangkan menjadi kawasan pengembangan kawasan desa wisata tidak hanya dilakukan dengan tujuan kegiatan satu wisata saja yaitu wisata bahari tetapi juga bisa melaksanakan kegiatan wisata dengan tujuan yang lain seperti kegiatan wisata rekreasi, lingkunagan, seni dan budaya, dan kegiatan wisata sejarah. Selain telaah analisis pemetaan potensi pengembangan kawasan desa wisata, maka kegiatan perencanaan juga dilakukan dengan telaah analisis terhadap kesiapan stakeholder masyarakat, pemerintah dan pihak swasta dalam mendukung pengembangan potensi kawasan Desa wisata di Kabuapten Bengkalis. Kemudian perencanaan pengembangan potensi Desa Wisata ini juga didukung adanya perencanaan penganggaran dan pada Anggaran APBD Kabupaten Bengkalis. Peran penting pemerintah dalam pengembangan kawasan wisata adalah menyediakan anggaran guna peningkatan semua aspek baik pokok maupun pendukung dalam pengembangan pariwisata. Diakui bahwa masalah anggaran merupakan masalah klasik pemerintah, oleh sebab itu perlu kolaborasi antar struktur pemerintahan dalam pengalokasian anggaran guna pengembangan kawasan wisata di daerah termasuk desa wisata di Kabuapten Bengkalis.

Tahapan pengorganisasian adalah langkah lanjut sebagai bentuk perwujudan dari perencanaan. Pengorganisasian berfungsi untuk memberikan atau mendistribusikan tugas atau wewenang/tanggung jawab dan sistem komunikasi serta mengkoordinasi kerja setiap bawahan di dalam suatu tim agar terorganisir dengan baik (Suprapto, 2011: 131). Pengorganisasian komunikasi menurut Suprapto (2011) juga melibatkan aspek komunikator, pesan, media, khalayak dan pengaruh yang diinginkan.

Tahapan lainnya yang dilakukan setelah perencanaan dalam pengembangan potensi Desa Wisata di Kabupaten Bengkalis adalah melakukan kesiapan pengorganisasian aktivitas komunikasi dalam pengembangan desa wisata. Melalui kesiapan lembaga struktural untuk pengembangan potensi Desa Wisata di Kabuapten Bengkalis dapat direalisasikan secara optimal. penggorganisasian pada manajemen pengembangan Potensi Desa Wisata Kabupaten Bengkalis. Dalam hal 
ini komunikator utamanya adalah Bidang Pariwisata Disparbudpora yang membawahi Pemerintah Desa yang memiliki potensi pariwisata pedesaan. Pemerintah Desa akan membawahi kelompok sadar wisata untuk mengelola pariwisata pedesaan.

Pelaksanaanmerupakan tahapaanuntuk merealisasikan rencana kerja seperti yang telah ditetapkan. Maksud dari pelaksanaan ini adalah membangun sistem mekanisme kerja, agar rencana kerja terealisasi dengan baik. Pelaksanaan adalah sebagai wujud perencanaan. Keikutsertaan kedua belah pihak dalam penyelenggaraan kegiatan sangat diperlukan. Penggerakan/aksi komunikasi dalam manajamen komunikasi merupakan arahan nyata yang diberikan kepada setiap unsur-unsur komunikasi untuk menjalankan tugas dan wewenangnya dalam melaksanakan program.

Pelaksanaan pengembangan potensi desa wisata dapat dilakukan dengan memanfaatkan potensi sumber daya alam dan sumber daya manusia yang ada. Dalam pelaksanaannya dilakukan oleh visi Kepala Desa yang berorientasi kepada orientasi kewisataan dan didukung oleh anggaran dari pemerintah Pusat dan daerah berupa dana alokasi desa dan dana pengembangan desa lainnya. Sehingga hal tersebut mengakibatkan desa wisata terpadu mampu terwujud dengan adanya keinginan bersama dari stakeholder dan pelibatan masyarakat lainnya.

Pengawasan dan evaluasi sering juga disebut pengendalian adalah salah satu fungsi manajemen yang berupa mengadakan penilaian, bila perlu mengadakan koreksi sehingga apa yang dilakukan bawahan dapat diarah kan ke jalan yang benar dengan maksud dengan tujuan yang telah digariskan semula. Proses pengawasan dan evaluasi terhadap kegiatan dialkukan sebagai upaya untuk memantau pelaksanaan kegiatan. Tahap pengawasan dan evaluasi belum sepenuhnya dilakukan oleh Disparbudpora Kabupaten Bengkalis dikarenakan program ini baru dimulai dan belum sepnuhnya mendapat dukungan dari, pemerintah, masyarakat dan pihak swasta dalam pelaksaannan pemgembangan potensi Desa Wisata di Kabupaten Bengkalis ini.

Pelibatan aktif dari Badan Pengelolaan Wisata Kabupaten Bengkalis menjadi sangat penting dalam pengawasan dan evaluasi dalam pengembangan Desa Wisata di ksbuapten Bengkalis. dengan adanya tahapan pengawasan dan evaluasi tersebut mampu menjadi bahan masukan dan saran untuk meningkatkan kinerja dan profesionalitas dari pelaku wisata di Kabupaten Bengkalis dan hal ini dapat berkontribusi terhadap model pengembangan kawasan desa wisata di Kabupaten Bengkalis secara terpadu.

Manajemen Komunikasi Dinas Pariwisata, Kebudayaan, Kepemudaan dan Olahraga dalam Program Pengembangan Potensi Desa Wisata di Kabupaten Bengkalis dapat digambarkan sebagai berikut: 
Gambar 1.

Model Manajemen Komunikasi Pengembangan Potensi Desa Wisata

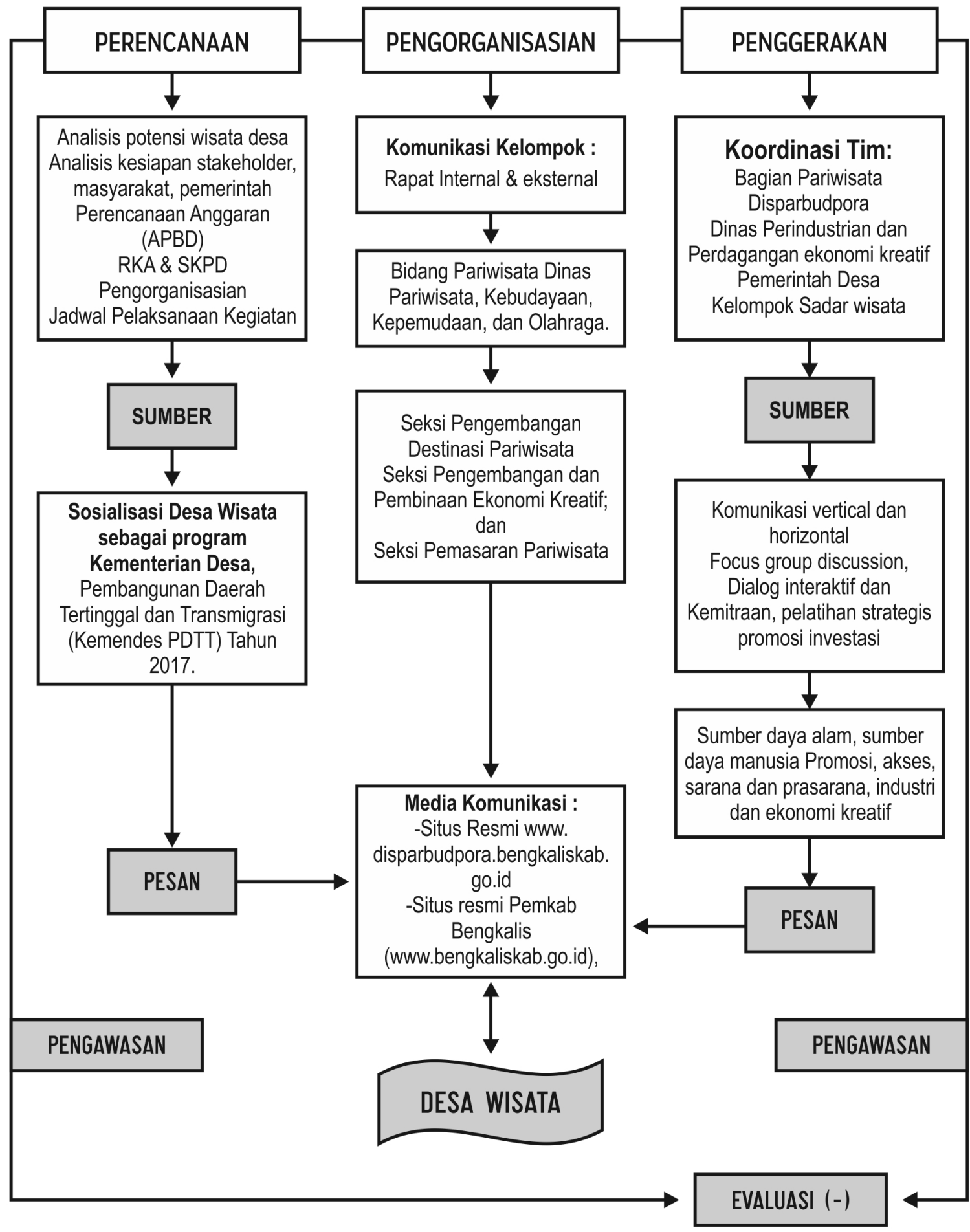

Sumber : Hasil olahan peneliti

Suatu organisasi, dalam hal ini dinas instansi pemerintah merupakan suatu sistem yang saling berhubungan dan bergantung dengan instansi lain dalam menjalankan kegiatannya. Kegiatannya tidak dapat 
berjalan baik tanpa dukungan pihak lain untuk mencapai tujuan bersama yang telah ditetapkan. Sistem akan menghubungkan semua lingkungannya baik itu lingkungan internal maupun eksternal, sehingga untuk mencapai tujuan tersebut harus adanya tata kelola yang baik dalam setiap hubungan dan interaksi, dalam hal ini manajemen sangat diperlukan agar dapat mencapai tahap demi tahap target dan sasaran yang telah dibentuk. Suatu hubungan dan interaksi tersebut akan terbentuk melalui komunikasi, sehingga dapat dikatakan bahwa komunikasi memiliki peranan penting sebagai penggerak aktivitas dalam proses manajemen. Dengan kata lain, suatu organisasi/ instansi harus memiliki pola manajemen komunikasi yang baik, komunikasi dalam tahap perencanaannya, komunikasi dalam tahap pengorganisasiannya, komunikasi dalam tahap pelaksanaannya, dan komunikasi dalam tahap pengawasan dan evaluasinya.

\section{KESIMPULAN}

Manajemen Komunikasi Dinas Pariwisata, Kebudayaan, Kepemudaan dan Olahraga dalam Program Pengembangan Potensi Desa Wisata di Kabupaten Bengkalis dilakukan dengan berbagai aktivitas. Kegiatan mengembangkan desa wisata merupakan bentuk aktivitas komunikasi parwisata. Perencanaan program pengembangan potensi Desa wisata di Kabupaten Bengkalis yang dilakukan oleh Dinas Pariwisata, Kebudayaan, Kepemudaan dan Olahraga merupakan aktivitas menajemen komunikasi utama.
Tahap pertama ini adalah perencanaan, tahap tersebut dimulai dari pemetaan terhadap potensi sumber daya alam di beberapa Desa yang layak untuk dikembangkan menjadi kawasan pengembangan kawasan desa wisata. Penggorganisasian pada manajemen komunikasi program pengembangan potensi Desa Wisata pengembangan Potensi Desa Wisata Kabuapten Bengkalis, komunikator utamanya adalah Bidang Pariwisata Dinbudparpora yang membawahi Unit Pelayanan Terpadu (UPT) Pemerintah Desa yang memiliki potensi pariwisata pedesaan. Koordinasi dengan berbagai pihak dilakukan dengan komunikasi vertical dan komunikasi horizontal. Proses Penggerakan (actuating) pada pada manajemen komunikasi program pengembangan potensi Desa Wisata dengan cara berusaha melakukan pembinaan desa wisata yang ada dengan melibatkan peran masyarakat di sekitarnya. Membentuk kelompok sadar wisata dan pembinaan ekonomi kreatif. Tahap pengawasan dan evaluasi komunikasi pada manajemen komunikasi program pembangan potensi Desa Wisata di Kabupaten Bengkalis belum sepenuhnya dilakukan oleh Dinas Kebudayaan pariwisata Kabupaten Bengkalis dikarenakan program ini baru dimulai dan belum sepnuhnya mendapat dukungan dari, pemerintah, masyarakat dan pihak swasta dalam pelaksaannan pemgembangan potensi Desa Wisata di Kabupaten Bengkalis.

\section{DAFTAR PUSTAKA}

Bungin, Burhan. 2015. Komunikasi Pariwisata. Jakarta: Prenada Group 
Devito, Joseph, A. 1997. Komunikasi Antarmanusia. Jakarta: proffesional Books

Hamidi, 2007. Metodologi Penelitian dan Teori Komunikasi. Malang: UMM

Idrus, Muhammad. 2007. Metode Penelitian Ilmu-ilmu Sosial : Pendekatan Kualitatif dan Kuantitatif, Yogyakarta: UII Press Yogyakarta, 2007

Kaye, M. (2004). Communication Management. Sydney: Prentice Hall.

Moleong, Lexy J. 2007. Metodologi Penelitian Kualitatif, Bandung, Remaja Rosdakarya.

Mulyana, Deddy. 2001. Ilmu Komunikasi; Suatu Pengantar, Remaja Rodakarya, Bandung.

Soedarsono, Dewi K. 2009.Sistem Manajemen Komunikasi (teori, model dan aplikasinya).Bandung: Simbiosa Rekatama Media

Suprapto, Tommy. 2009.Pengantar Ilmu Komunikasi (dan peran manajemen dalam $\quad k$ omunikasi). Yogyakarta: CAPS

Suwena, I Ketut. 2010. Pengetahuan Dasar Ilmu Pariwisata. Denpasar: Udayana Press.

West, R. \& Lynn H.T. 2008, Pengantar Teori Komunikasi; Analisis dan Aplikasi, Edisi 3, Buku 1, penerjemah Maria Natalia Damayanti Maer, Salemba Humanika, Jakarta.
Yasir, et.al. 2016. "A Model of Communication to Empower Fisherman Community in Bengkalis Regency", MIMBAR; Sosial Pembangunan, Vol. 33, no 2, pp 228237. DOI: https://doi.org/10.29313/ mimbar.v33i2.2135.

Yoeti, Oka. 1996. Pengantar Ilmu Pariwisata. Angkasa. Bandung

Sumber lain:

Darsono. 2005. Pengertian Desa. Diakses tanggal 10 Maret 2018 dari http:// desasentonorejo.wordpress.com/babii/. Angkasa: Bandung

Indonsia Ecotourism Network. 2002. Diakses tanggal 10 Maret $2018 \quad$ http:// www.indecon.or.id/

Nurjanah, Yasir. 2014. Strategi Komunikasi Inovasi dalam Mengembangkan Potensi Desa Wisata Meskom di Kecamatan Bengkalis. Pekanbaru: https://repository.unri.ac.id/xmlui/ bitstream/handle/123456789/4076/isi. pdf? sequence $=2$

Yuliani. 2013. Strategi komunikasi Dinas Kebudayaan Pariwisata (Disbudpar) dan Dinas Komunikasi dan Informasi (Diskominfo) dalam Meningkatkan Kunjungan Wisatawan di Desa Pampang Kota Samarinda. Samarinda: http://ejournal.ilkom.fisip-unmul.ac.id/ site/wp-content/uploads/2013/09/ JURNAL\%20YULIANIedit\%20(0919-13-08-05-04).pdf 